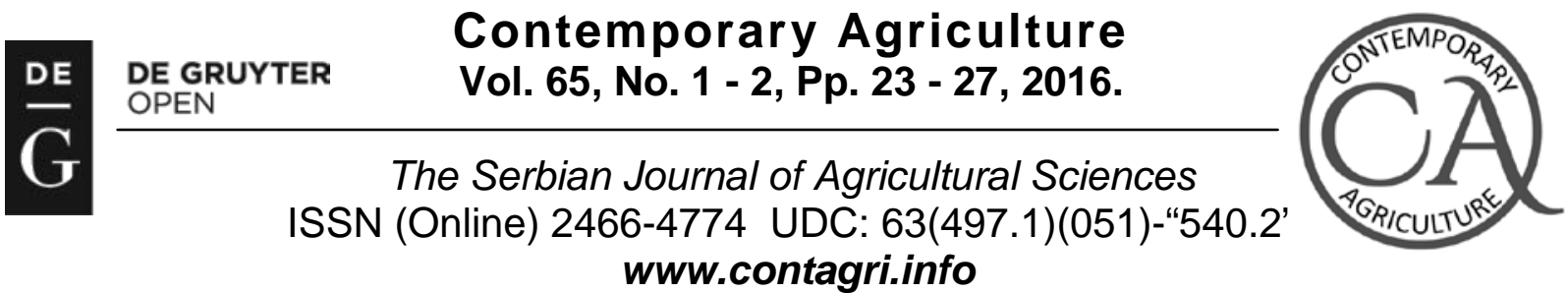

Review paper

UDC: $572.023: 597.555 .3$

DOI: $10.1515 /$ contagri-2016-0004

\title{
ALTERNATIVE CEREALS IN CARP (CYPRINUS CARPIO L.) NUTRITION
}

\author{
Goran MARKOVIĆ , Milomirka MADIĆ ${\text {, Nikola BOKAN }{ }^{1} \text {, Miroslav ĆIRKOVIĆ }}^{2}$
}

\begin{abstract}
Summary: Due to their high carbohydrate content, cereals are the main source of energy in human, livestock and fish diets, with wheat and maize being the most commonly used crops. Although these two crops, along with rice, satisfy about 50\% of human energy requirements, it is necessary to introduce other crops, which are of minor commercial importance. This necessity has been intensified by the growing needs of aquaculture, particularly with respect to carbohydrate requirements. Cereal grains account for an average of 35-45\% of the feed ration for common carp (Cyprinus carpio). Experiments have been conducted on the use of barley, triticale and rye as substitutes for wheat and maize. The grains of these replacement cereals are preliminarily subjected to gelatinisation due to the high content of crude starch. Results indicate the possibility of partial or complete substitution (for maize) in some fish feeds. The usability (feed value) of cereals in fish nutrition is ranked in the order: wheat > triticale > maize > barley > rye.
\end{abstract}

Key words: carp nutrition, barley, triticale, rye

\section{INTRODUCTION}

Human nutrition is largely characterised by an insufficient intake of quality food, particularly in terms of the quality and quantity of animal products. It is a well-known fact that fish meat is a source of highly valuable and easily digestible proteins, unsaturated fatty acids, vitamins and microelements (Vladau et al., 2008). Therefore, the intensification of fish production has become a priority in some parts of the world. While open water fishing has shown stagnation and a slight decline (induced by overexploitation and increasing pollution), fish production in global aquaculture has exhibited a stable growth tendency. In 2010-2012, the total average fish production was $153.94 \times 10^{6}$ t, with $62.92 \times 10^{6} \mathrm{t}(40.87 \%$ of total production) originating from aquaculture. The average consumption during the period was $18.9 \mathrm{~kg} / \mathrm{capita}$ (Anonymous, 2014).

Aquaculture in Serbia is dominated by fish farming, while frogs, crabs and other aquatic organisms have a negligible presence. Fishponds in Serbia cover about 14,000 ha, with $99.9 \%$ of them being cyprinid, and only $0.1 \%$ salmonid. The total annual production of consumable fish is estimated at 15,000 t, with common carp (Cyprinus carpio) production accounting for more than $80 \%$ of the total production (Marković et al., 2012a).

The common carp (C.carpio) is a benthophagous species that has an omnivorous diet. It is raised in semi-intensive or intensive farming systems. Under semi-intensive conditions, dietary protein requirements are satisfied from natural food supplies (zooplankton and benthic fauna), and its carbohydrate requirements through cereal consumption (Rašković et al., 2011). In intensive farming systems, nutritional needs are ensured through complete feeds that provide a balanced nutrient composition (Stanković et al., 2011). In feeds for carp species, fishmeal is the main source of highly valuable and easily digestible proteins (Watanabe, 2002). Open water catch limits have increasingly directed attention toward alternative protein sources, such as certain groups of plants (specifically soybean and other representatives of the family Fabaceae), waste materials from the slaughter industry and other sources (Ćirković et al., 2015). The proteins of cereals (Poaceae) have a lower biological value than other plant families (Fabaceae in particular), due to the lower content of

\footnotetext{
${ }^{1}$ Goran Marković, PhD, Associate Professor, Milomirka Madić, PhD, Full Professor, Nikola Bokan, PhD, Associate Professor, University of Kragujevac, Faculty of Agronomy, 32000 Čačak, Serbia

${ }^{2}$ Miroslav Ćirković, PhD, Principal Research Fellow, Scientific Veterinary Institute „Novi Sad“, 21000 Novi Sad, Serbia

Corresponding author: Goran Marković, email: goranmsv@kg.ac.rs, phone: +381 32222584
} 
essential amino acids and the presence of phytates, betaglucans and other inhibitors of amylolytic and proteolytic enzymes (Mazurkiewicz, 2009). Due to its short supply, fish oil (as the best source of fatty acids) has been increasingly replaced in carp feeds with oils derived from other plants, primarily flaxseed oil and rapeseed oil (Marković et al., 2014b; Ljubojević et al., 2015).

Cereals (maize and wheat in particular) are major sources of energy not only in human nutrition, but also in livestock and fish diets. Demographic expansion and growing aquaculture requirements are demanding the use of other cereal crops in fish nutrition. Moreover, cereal production without the use of synthetic pesticides and mineral fertilisers in organic and integrated farming systems may contribute to the development of organic aquaculture (Bokan, 2000; Marković and Lujić, 2014a).

This paper presents the potentials and limitations of using barley, triticale and rye as substitutes for commercially important cereals in carp nutrition.

\section{USABILITY OF BARLEY IN THE NUTRITION OF CYPRINID FISH SPECIES}

Barley (Hordeum vulgare L.) is a self-pollinating species belonging to the grass family (Poaceae). Owing to its distinct polymorphism and tolerance to a wide range of unfavourable agroenvironmental conditions, this species has the widest distribution range among modern cereals (Pržulj et al., 2010). Controlled crossing between wild barleys has resulted in the development of cultivated barleys grouped into multiple-rowed and two-rowed barleys. Barley cultivars used as livestock feed have a high protein content (up to 20\%). Selection has produced malting barley cultivars with a lower protein content (8-12\%) and a high starch content (> 60\%) (Jevtić et al., 1986). There is a high variability in the chemical composition of barley grain as induced by cultivar, cultural practices and agroenvironmental conditions (Madić et al., 2009). Barley grain is similar in chemical composition to the grain of other cereals, particularly wheat and triticale (Marković et al., 2013b).

The main constraint to a wider use of barley in the nutrition of carp and other fish species is its high crude fibre content (5\%) compared to commercially more important cereals such as wheat (2.6\%) and maize (2.3\%) (Janković et al., 2011). Crude starch digestibility in the digestive tract of carp is about $70 \%$, which along with non-digestible fibres decreases the feed conversion ratio and deteriorates the quality of water (Mitrović-Tutundžić et al., 1996). Extrusion involves starch gelatinisation, which increases starch digestibility to 90\% (Ćirković et al., 2002).

In the experiment evaluating carp species with a pre-consumption weight of 500-800g, different fish feeds were tested for the degree of digestibility of organic components (Marković et al., 2013b). Fish feeds were composed of 50\% constant ingredients (50\% soybean meal, 35\% wheat flour, 10\% soybean oil and 5\% vitamin premix), and wheat, maize or barley making up the other half. All three types of feed had a uniform content of proteins (23.27-23.38\%) and lipids (8.53-9-04\%). The degree of digestibility was the difference in the content of nutritional components between the fish feed and fish faeces. The experiment was conducted over a period of 3 weeks in a recirculating system at a constant water temperature $\left(23^{0} \mathrm{C}\right)$ and a daily feeding rate of $3 \%$ of body weight. Results indicate a considerably higher degree of digestibility of almost all nutritional components in the fish feed solely composed of wheat compared to the other two cereal crops, particularly barley. However, the digestibility of maize lipids $(82.01 \%)$ was somewhat higher than that of wheat lipids (79.84\%).

Allameh et al. (2000) stressed the potential of using barley as a substitute for maize in feeds for common carp. Maize as a major carbohydrate source was replaced with different levels of barley and millet (0\%, 25\%, 50\%, 75\% and 100\%). The feed conversion ratio in all diets having barley and millet was higher than in the control diet that contained maize only. Although the differences were not statistically significant, their values and the highest specific growth rate of carp receiving feeds having $50 \%$ and $100 \%$ barley substitution indicate success in replacing maize with this cereal crop.

\section{USABILITY OF TRITICALE IN THE NUTRITION OF CYPRINID FISH SPECIES}

Triticale (x Triticosecale) is a crop species derived from a controlled cross between wheat (Triticum sp.) and rye (Secale cereale). Combining the genomes of the parental species has resulted in hybrids that exhibit properties of both wheat (high potential for grain yield and quality) and rye (resistance to low temperatures, diseases and low humus content in the soil) (Janković et al., 2011). The high protein content of triticale (in some cultivars up to 20\%) is indicative of a high biological value of the grain (Đekić et al., 2011). In addition, triticale demonstrates better tolerance to low soil pH compared to most wheat cultivars (Madic et al., 2013).

Vacha et al. (2007) analysed the effect of different supplemental cereal grains (maize, wheat and triticale) on carp meat yield and quality under diverse farming conditions (extensive and semi-intensive systems). The experimental period was 8 months, and included carp individuals with an initial average weight of $1.13 \mathrm{~kg}$. In the first fish pond, no cereals were added, and the carp consumed only natural food (extensive farming). In the second, third and fourth 
fishponds, the carp were fed maize, wheat and triticale, respectively. Apart from examining total yield and feed conversion ratio, the analysis involved testing the fish meat of the experimental carp for total fats and individual fatty acids.

The lowest weight gain was recorded in the fishpond where carp received solely natural food (without cereal-based feed). Feeding triticale led to a somewhat lower yield and lower feed conversion ratio compared to maize- and wheatbased diets. The meat of carp fed natural food contained the lowest percent of total fats, but the highest percent of polyunsaturated fatty acids (25.97\%). The total fat content in the meat of carp that consumed triticale was lower than in the other two groups fed maize and wheat. The total content of polyunsaturated fatty acids (PUFAs) in carp fed triticale (12.59\%) was slightly higher than in carp fed wheat (12.14\%), and lower than in carp that consumed maize (15.41\%).

It is a well-known fact that the intake of foods rich in polyunsaturated fatty acids (particularly n-3 fatty acids) has a positive effect on the cardiovascular system and overall human health (Simopoulos, 2008). This research, along with other studies (Mazurkiewicz, 2009; Marković et al., 2012b), indicates the potential of partial or complete substitution of commercially important cereals (wheat and maize) with triticale in cyprinid diet without any substantial reduction in the nutritional properties of the fish produced (Marković et al., 2013a).

\section{USABILITY OF RYE IN THE NUTRITION OF CYPRINID FISH SPECIES}

Rye (Secale cereale) is a small grain crop widely cultivated in the uplands of Serbia. It spread from its place of origin (Asia Minor) to all continents, and acquired a particularly wide range in northern parts of Europe. Compared with wheat, rye exhibits better growth and higher tolerance to low temperatures, drought and low nutrient contents in the soil (Jevtić et al., 1986). The average grain protein content of $11.8-14.6 \%$ makes rye a quality foodstuff, in addition to the other contributing properties i.e. the high content of plant fibres, vitamins A, E and vitamin B complex, and some minerals (particularly Mn). Apart from being used in human and livestock diets, rye is also used as a raw material for the alcohol and alcoholic beverage industry. In recent years, rye flour has been increasingly used in diets for people affected by diabetes mellitus and celiac disease due to its high fibre content and low gluten content (Tovoli et al., 2015).

Pryzbyl and Mazurkiewicz (2004) conducted an experiment to compare the nutritional properties of extruded grains of barley, wheat, triticale and rye used in feeds for carp. A 60-day test was performed on fish with an initial average weight of $200 \mathrm{~g}$ under controlled farming conditions (water temperature ranged from $17.5-24.2^{0} \mathrm{C}$, with variations in dissolved $\mathrm{O}_{2}$ from $2.30-7.10 \mathrm{mg} / \mathrm{dm}^{3}$ ). The fish were analysed for dry weight, total protein, crude fat and crude ash at the beginning and at the end of the experiment. The feeds in all variants contained fish meal (14-17\%), blood meal (88.5\%), yeast (4\%), soybean meal (13.5\%) and rapeseed meal (5.5-8.0\%). The rest (43\%) included extruded grains of barley (variant I), wheat (II), triticale (III) and rye (IV).

The results of the experiment showed that the wheat-based diet had the highest positive effect on the properties analysed. The absence of significant differences between the experimental variants confirms that the feeds containing extruded grains of the other types of cereals have an equal usefulness for carp under intensive farming conditions.

\section{CONCLUSION}

Cereals are the main source of energy in fish diet, with wheat and maize being the most commonly used crops. Demographic expansion and growing aquaculture requirements are demanding the use of other cereal crops, which are of minor commercial importance. Experiments have been conducted on the use of barley, triticale and rye as substitutes for wheat and maize. The high resistance to unfavourable agroenvironmental conditions makes these species suitable as crops in the uplands of Serbia. Due to the high crude starch content (60-70\%), the grains of these cereals are subjected to gelatinisation to increase starch digestibility.

Results suggest possibilities for partial or complete substitution of wheat and maize in certain fish feeds. Specifically, considerable success has been achieved with triticale, which also contains high protein levels. The usability (feed value) of cereals in fish nutrition is ranked in the order: wheat $>$ triticale $>$ maize $>$ barley $>$ rye.

\section{ACKNOWLEDGMENT}

The experiment presented in this paper is a part of Project no. 114-451-796/2015 by Provincial secretariat for science and technological development of Vojvodina and a part of an Integrated Interdisciplinary Research Project number III 46012, funded by Serbian Ministry of Education, Science and Technological Development. Authors also thank to dr. Dejan Delibašić for remarkable help in design of the experiment 


\section{REFERENCES}

ALLAMEH, F.S., MAHBOOBI, S.N., POURREZA, J., ESTEKI, A.: Effect of Substituting Barley and Millet Diets for Corn on Growth and Feed Conversion Ratio of Common Carp (Cyprinus carpio L.). The Journal of Science and Technology of Agriculture and Natural Resources, Water and Soil, 4(3), 89-97, 2000.

ANONYMOUS: The State of World Fisheries and Aquaculture. FAO Rome, pp. 1-223, http://www.fao.org, 2014.

BOKAN, N.: Prednosti kukuruza kao zdravstveno bezbedne hrane. Eko-konferencija, Tematski zbornik II, Novi Sad, pp. 93-98, 2000.

ĆIRKOVIĆ,M., JOVANOVIĆ, B., MALETIN, S.: Ribarstvo. Poljoprivredni fakultet Novi Sad, pp. 1-359, 2002.

ĆIRKOVIĆ, M., KARTAlOVIĆ, B., BABIĆ, J., PELIĆ, M., NOVAKOV, N., JOVANIĆ, S., ĐORĐEVIĆ, V.: Implementation of fishing technologies and sustainable development in slaughterhouse systems. VII International Conference "Water \& Fish”, Belgrade-Zemun, Serbia, 10 - 12 June 2015, pp 29-32.

ĐEKIĆ, V., MILOVANOVIĆ, M., STALETIĆ,M., PERIŠIĆ,V.: Sadržaj proteina različitih sorti Tritikale u periodu 2007-2008. godine. Zbornik naučnih radova Instituta PKB Agorekonomik, 17(1-2), 49-54, 2011.

JANKOVIĆ, S., JOVANOVIĆ, R., ĆIRKOVIĆ, M., LJUBOJEVIĆ, D., RAKIĆ, S., MILOŠEVIĆ, N.: Importance and use of grains in fish nutrition. V International Conference “Aquaculture \& Fishery”, Faculty of Agriculture, BelgradeZemun, Serbia, 1-3 June, 2011, pp 103-109.

JEVTIĆ, S., ŠUPUT, M., GOTLIN, J., PUCARIĆ, A., MILETIĆ, N., KLIMOV, S., ĐORĐEVSKI, J., ŠPANRIG, J., VASILEVSKI,G.: Posebno ratarstvo, I deo. Naučna knjiga, Beograd, pp. 1-415, 1986.

LJUBOJEVIĆ, D., NOVAKOV, N., PELIĆ, M., ĐORĐEVIĆ, V., RADOSAVLJEVIĆ, V., JOVANOVIĆ,R., ĆIRKOVIĆ, M.: Vegetable oils in nutrition of cyprinid fish species. VII International Conference "Water \& Fish", Faculty of Agriculture, Belgrade-Zemun, Serbia, 10-12 June 2015, pp 345-349.

MADIĆ, M., PAUNOVIĆ, A., KNEŽEVIĆ, D., ZEČEVIĆ, V.: Grain Yield and Yield Components of Two-Row Winter Barley Cultivars and Lines. Acta Agriculturae Serbica, XIV (27), 17-23, 2009.

MADIC, M., ĐUROVIC,D., JELIC, M.,RASTIJA,M., PAUNOVIC,A., BOKAN,N.: Grain yield and yield components of Triticale on an acid soil depending on mineral fertilisation and liming. $48^{\text {th }}$ Croatian and $8^{\text {th }}$ International Symposium of Agriculture. Dubrovnik, Croatia, 17-22. February 2013, pp. 520-524.

MARKOVIĆ, G.S., ĆIRKOVIĆ, M.A., MALETIN,S.A.: The role of allochthonous (non-native) fish species in Serbian aquaculture. Journal of Central European Agriculture, 13(3), 539-544, 2012a.

MARKOVIĆ,G., MADIĆ,M., ĆIRKOVIĆ,M., BRKOVIĆ,D.: Tritikale kao komponenta riblje hrane. XVII Savetovanje o biotehnologiji, Čačak, Srbija, 6-7.April 2012, pp. 270-274, 2012b.

MARKOVIĆ, G., ĆIRKOVIĆ, M., LUJIĆ, J., PANTOVIĆ, J.: Comparison of the nutritive value of wheat and triticale in fish diet. VI International Conference „Water \& Fish“, Belgrade-Zemun, Serbia, 12-14 June 2013, pp 233-237, 2013a.

MARKOVIĆ, G., MADIĆ,M., LUJIĆ, J.: Ječam (Hordeum vulgare L.) u ishrani riba. XVIII Savetovanje o biotehnologiji, Čačak, Srbija, 15-16. Mart 2013, pp. 417-421, 2013 b.

MARKOVIĆ, G., LUJIĆ, J.: Use of minor cereals and small grains in fish nutrition. V International Scientific Symposium “Agrosym 2014”, Jahorina, Bosnia and Herzegovina, 23-26 October 2014, Abstracts, pp.236, 2014.

MARKOVIĆ,G., LUJIĆ, J., PANTOVIĆ, J., RADOVANOVIĆ, M., MAŠKOVIĆ, P.: Biljna ulja u ishrani riba. XIX Savetovanje o biotehnologiji, Čačak, Srbija, 7-8.Mart 2014, pp. 435-439, 2014.

MAZURKIEWICZ., J.: Utilization of domestic plant components in diet for common carp Cyprinus carpio L. Archives of Polish Fisheries, 17, 5-39, 2009.

MITROVIĆ-TUTUNDŽIĆ, V., HRISTIĆ, Đ., MARKOVIĆ, Z.: Ribarsko korišćenje vodoprivrednih objekata i drugih antropogenih voda. Vodoprivreda, 28, 227-232, 1996.

PRZYBYL, A., MAZURKIEWICZ., J.: Nutritive value of cereals in feeds for common carp (Cyprinus carpio L.). Czech Journal of Animal Science, 49 (7), 307-314, 2004.

PRŽUlJ, N., MOMČIlOVIĆ, V., NOŽINIĆ, M., JESTROVIĆ, Z., PAVLOVIĆ, M., OBROVIĆ, B.: Značaj i oplemenjivanje ječma i ovsa. Ratarstvo i povrtarstvo, 47(1), 33-42, 2010.

RAŠKOVIĆ, B. S., STANKOVIĆ, M. B., MARKOVIĆ, Z. Z., POLEKSIĆ, V. D.: Histological methods in the assessment of different feed effects on liver and intestine of fish. Journal of Agricultural Sciences, 56 (1), 87-100, 2011.

SIMOPOULOS, A.P.: Omega-3 Fatty Acids in Inflammation and Autoimmune Diseases. Journal of the American College of Nutrition, 21(6), 495-505, 2008.

STANKOVIĆ,M., DULIĆ,Z., MARKOVIĆ,Z.: Protein sources and their significance in carp (Cyprinus carpio L.) nutrition. Journal of Agricultural Sciences, 56 (1), 75-86, 2011.

VLADAU, V.V., BUD,I., REKA,S.: Nutritive value of fish meat comparative to some animals meat. Bulletin UASVM Animal Science and Biotechnologies, 65(1-2): 301-304, 2008. 
TOVOLI, F., MASI, C., GUIDETTI, E., NEGRINI,G., PATERINI,P., BOLONDI, L.: Clinical and diagnostic aspects of gluten related disorders. World Journal of Clinical Studies, 3(3), 275-284, 2015.

WATANABE, T.: Strategies for further development of aquatic feeds. Fisheries Science 68, 242-252, 2002.

\title{
ALTERNATIVNE ŽITARICE U ISHRANI ŠARANA (CYPRINUS CARPIO L.)
}

\author{
Goran MARKOVIĆ, Milomirka MADIĆ, Nikola BOKAN, Miroslav ĆIRKOVIĆ
}

Izvod: Zbog visokog sadržaja ugljenih hidrata žitarice predstavljaju osnovni energetski izvor u ishrani čoveka, domaćih životinja i riba. Za tu svrhu se najviše koriste pšenica i kukuruz. Mada ove dve vrste, zajedno sa pirinčem, zadovoljavaju oko 50\% energetskih potreba čovečanstva, potrebno je uvesti i druge, komercijalno manje značajne vrste žitarica za ovu namenu. Tome doprinosi i rastuće potrebe akvakulture koja za gajenje riba zahteva velike količine ugljenih hidrata. U smešama za ishranu šarana žitarice u proseku predstavljaju 35-45\% ukupne mase.

Vršeni su ogledi sa supstitucijom pšenice i kukuruza ječmom, tritikaleom i raži. Zrna ovih žitarica su prethodno podvrgnuta procesu želatinizacije zbog visokog sadržaja sirovog skroba. U ogledu kojim je analiziran stepen svarljivosti najvažnijih komponenata u smešama za ishranu šarana, uočen je manji stepen svarljivosti proteina (71.86\%) i lipida $(66.70 \%)$ u smeši koja je sadržavala ječam u poređenju sa kukuruzom i pšenicom. Ogledom kojim su poređeni prinosi i upotrebne vrednosti mesa šarana hranjenim prirodnom hranom, tritikaleom, pšenicom i kukuruzom, uočen je veći koeficijent konverziije hrane (3.77), manji ukupan prinos (0.915 kg/ind.) i niži sadržaj ukupnih masti (9.72\%) kod šarana hranjenih tritikaleom u poređenju sa pšenicom i kukuruzom. Međutim, ukupan sadržaj polinezasićenih manih kiselina je u mesu šarana hranjenih tritikaleom (12.59\%) bio neznatno viši od šarana hranjenih pšenicom (12.14\%) i statistički značajno viši od šarana koji su konzumirali kukuruz (15.41\%).

Analizom rezultata autora rada i dostupnih referentnih podataka, može se zaključiti da tritikale poseduje bolja nutritivna svojstva u poređenju sa druge dve žitarice. Dobijeni rezultati ukazuju na mogućnost korišćenja ovih žitarica za delimičnu ili potpunu supstituciju komercijalno značajnih žitarica (u slučaju kukuruza) u pojedinim smešama za ishranu riba. Upotrebna vrednost žitarica za ishranu šaranskih riba može biti rangirana ovim redosledom: pšenica $>$ tritikale $>$ kukuruz $>$ ječam $>$ raž.

Ključne reči: ishrana šarana, ječam, tritikale, raž

Received / Primljen: 30.05.2016.

Accepted / Prihvaćen: 20.06.2016. 